\title{
Coping With Different Generations In The Workplace
}

Elena Comperatore, Hodges University

Frederick Nerone, Hodges University

\begin{abstract}
There was a time when diversity in the workplace was thought of as different races, religions, ethnic backgrounds and, gender. An emerging form of workplace diversity is the different generational groups. The generations in almost any given company ranges from Veterans to Baby Boomers to Gen Xers to Gen Yers. With such a large age gap and associated attitudinal and behavioral differences, managers are facing a difficult leadership task. Employees are also facing the difficult task of how to get along with and work with coworkers of different generations. Employers, managers, and employees must learn how to bridge the gap between the age generations, and capitalize on those differences to enhance organizational effectiveness.
\end{abstract}

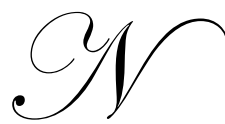

early $60 \%$ of HR managers at large companies say they've observed office conflicts that flow from generational differences, according to the Society for Human Resource Management" (Kadlec, 2007, pg. 50). Veterans or Radio Babies as they are sometimes called were born between the years of 1925 and 1945 (Carter, Pg. 3). Baby Boomers are the people born between 1946 and 1964 (Accounting Office Report, 2004, Pg. 6), Generation Xers were born between 1965 and 1981 (Pg. 6), and Gen Yers, also called the Millennium Generation and Echo Boomers were born between 1982 and 2000 (Pg. 6). "For the first time in American history, corporations are challenged with managing four generations of employees at once, each with different values, expectations, and attitudes" (Kyles, 2005, Managing Your Multigenerational Workforce). These different age groups are often working side by side and it is important for everybody that they work together as well.

\section{Number of People in Each Group}

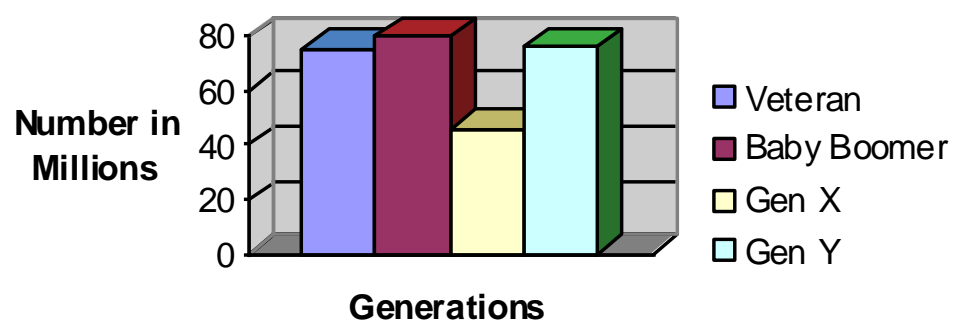

(Lancaster \& Stillman, 2003, When Generations Collide)

\section{VETERANS}

A few terms exist when speaking of the Veterans, such as Radio Babies, Silents, and Traditionists, however they all mean the same thing. The term Veterans is pretty obvious, but Radio Babies comes from the fact that "radios were a staple in many American homes when this generation was growing up, and TV has yet to come" 
(Gravett, 2007, pg. 34). While TV did become available during this generation, not many families had one and there were only three networks available. "Three major TV broadcast stations, NBC, ABC, and CBS, were available over the airways. These three stations served as the entire nation's broadcast system" (The Forgotten Generations, 2001). Each generation is different in many ways than the next. No matter what you call them, they are an important generation and are highly underestimated and understood.

"Silents are about $95 \%$ retired at this point. In a few short years virtually no Silent will command an industry, a battlefield, anything at all. They will have mostly gone well into the background" (Brett, The Silent Generation).

Veterans are one of our founding generations. "They are the generation whose vision and hard work created the United States as we know it today - a bold, powerful, prosperous, vital, modern democracy with all of its inherent challenges and paradoxes" (Zemke, 2000, Pg. 29). A few examples are the Great Depression, WWII and the attack at Pearl Harbor. "These people who finally brought you civil rights, an unparalleled national wealth in the arts and commerce, and unimaginable advances in science and technology" (www.univcon.com). "They built a space program and landed a man on the moon. They created miracle vaccines, and wiped out polio, tetanus, tuberculosis and whooping cough" (Zemke, 2000, Pg. 29).

There are certain characteristics that set each generation apart from the others. Some of the characteristics that set the Veterans apart from the other generations, according to the Employee Development Center at the East Tennessee State University (www.etsu.edu) are:

- $\quad$ Patriotism - Grew up during the depression and WWII

- $\quad$ Loyalty - To their families, country and careers

- $\quad$ Faith in Institutions

- $\quad$ Have a military influenced top-down approach

- $\quad$ They value logic and discipline

- $\quad$ Do not like change

- $\quad$ Provide a stable environment, probably because when growing up they did not have one

Something that is important for all the generations to remember is that the veterans have a great deal of experience, they have been in the workforce the longest. Some other notable characteristics of this great generation are mentioned on www.thinkquest.org are:

\section{- $\quad$ Cautious \\ - Unadventurous \\ - Unimaginative \\ - Withdrawn and Silent}

Many companies such as Home Depot are intentionally hiring Veterans because of their strong work ethics. They still believe that experience should go further than education and technological expertise. Veterans are upset when they are looked down upon by younger generations because they are not as technologically advanced. Unlike some of the generations to follow, they also believe that if they get a job, they should keep it and not jump from job to job.

According to Zemke, Raines and Filipczak in their book "Generations at Work: Managing the Clash of Veterans, Boomers, Xers and Nexters in Your Workplace", the Veterans have some notable core values that set them apart from the other generations. Looking back at all that took place in the world when this generation was growing up; it is clear why most Veterans have these core values: 


$\begin{array}{ll}\text { - } & \text { Dedication/Sacrifice } \\ \text { - } & \text { Hard work } \\ \text { - } & \text { Lonformity } \\ \text { - } & \text { Respect for authority } \\ \text { - } & \text { Patience } \\ \text { - } & \text { Delayed reward } \\ \text { - } & \text { Duty before pleasure } \\ \text { - } & \text { Adherence to rules } \\ & \text { Honor }\end{array}$

As with most parents, Veterans tried to instill these values onto their children. As with other generations some of these values were passed along. This generation has lived through some of the worst times this country has seen in the past hundred years or so, with the wars, the depression and illnesses. Many people were left with absolutely nothing, and some of them made a comeback and will gladly sit and tell you their stories of survival. Veterans are proud of where they came from, who they are and what they had to go through to get there.

A note about the personal life of the Veterans is that they were "the earliest marrying group in American History" and this generation also started a "divorce epidemic". Men were marrying around the age of 23, while women were marrying as young as 20 . The high rate of divorces was most likely due to being married at such a young age. (Silent Generation, www.thinkquest.org).

When training these Veterans, there are a few important things to remember. They will more than likely show up at least half an hour early. They want to be able to look over training materials to obtain a comfort level with them, get a seat up front so they can see and hear clearly and maybe have a cup of coffee and chat with some coworkers. To them, the trainer will be an authority figure. This is a reason why they are able to sit through longer lectures and training sessions than the younger generations. Even though this generation is getting older, and many are retiring, there are still some that want to continue working, and learning new skills to help them in their careers or volunteer work (Gravett, 2007, Pg. 153).

Traditionalists like to think they are building a legacy when mapping out their career goals. They feel it is important to spend a lifetime with one company, or at least in the same field. Some companies do not see this nowadays, they see somebody that is over the hill and getting ready to retire. Meanwhile, Traditionalists set a career path for themselves early on, and plan on sticking to it until they have achieved it. This can be difficult in some companies now because the career paths are not the same as they used to be. There are so many more options and paths to take.

Quite a few famous people were in this era. A few of these men and women are Margaret Thatcher, Queen Elizabeth II, Martin Luther King, Jim Henson, Bob Dylan, Aretha Franklin and Dustin Hoffman (The Silent Generation, www.thinkquest.org).

\section{BABY BOOMERS}

According to the U.S. Census, as of July 1, 2005, there were 78.2 million living baby boomers in the United States. This makes them "the largest single sustained surge of the population in the history of the U.S." (Accounting Office Report, 2004, Pg. 6). Once a baby boomer reaches the age of 62, they are eligible to collect Social Security, and in January 2008 the oldest baby boomer will reach this age (Greenblatt, 2007). "For the next 18 years, a member of the baby boom generation - the 78 million born between 1946 and 1964 - will reach that age every eight seconds" (Greenblatt).

Each generation is different in many ways than the next. There are certain characteristics that set each one apart. Some characteristics that describe the baby boomers, according to the Employee Development Center at East Tennessee State University (www.etsu.edu) are: 
- Idealistic - having an ultimate goal or objective

- Optimistic - anticipate the best possible outcome

- Question authority

- Want to build a stellar career

- $\quad$ The considered rewards for work to be

○ Money

- Title

- Recognition

Most terms used to describe Baby Boomers are positive, however, there are a few negative stereotypes out there. Some are that they are greedy and materialistic (Gravett, 2006, Pg. 38). Some other notable characteristics, mentioned in The Accounting Office and Administration Report are that they:

- Value creativity.

- $\quad$ Love adventure and take risks.

- $\quad$ Are independent.

- Willingly work long hours.

- $\quad$ May leave their children home alone.

- $\quad$ Are somewhat permissive.

- Have discovered that lifetime employment is uncertain.

Of the four generations currently in the workforce, Baby Boomers are the best educated. The main reason for furthering their education was to have better lifestyles (Gravett, 2006, Pg. 39). It is important that employers keep this in mind when hiring, training and retaining Boomers. "By 2012, the group of workers aged 55 and older will grow to 19.1 percent of the total workforce" (Gravett, 2006, Pg. 77).

Even though Boomers range in age from 43-61, they still want a job or a first or second career that offers career advancement. This does not necessarily mean promotions, but means "job enhancement, job rotation, or short-term assignments and projects" (Gravett, 2006, Pg. 79). When it comes to job enhancement, they want tasks that are more advanced and challenging, and by job rotation, they would like to try a different position with the company, but not necessarily one that is a promotion. They really care about their work challenging "their critical thinking skills and ignite a spark of enthusiasm. Boomers are crying out for work that doesn't bore them" (Gravett, 2006, Pg. 81). "Surveys conducted by AARP, the main advocacy organization for older Americans, show that up to 80 percent of boomers intend to work past 65 . Many have expressed the desire to pursue entirely new second careers, such as social work or teaching" (Greenblatt, 2007).

Continued training throughout their careers is a great way to keep the Baby Boomers happy with their work. It does not have to be the traditional training that is given to new employees, or even traditional college education. "Xavier University in Cincinnati, Ohio, offers a Senior Management Certificate Program that brings senior managers up to date with the latest management technology but doesn't require the same length of time as a graduate degree" (Gravett, 2006, Pg. 82). "A younger worker is more likely to use training as an opportunity to make a move to a better job with another company. The older worker will likely stay with the organization" (Belling, 2007).

Because of their expertise and experience, they would like to be respected by the younger generations. They have 'been there and done that' and would like to share their successes and failures with younger generations; to mentor them. Saving their younger coworkers from making the same mistakes as them is important to Boomers.

According to Linda Gravett and Robin Throckmorton in "Bridging the Generation Gap", Boomers are looking for more than just respect for their experiences and continuing education, they are also looking for: 
- $\quad$ Flexible work schedules - allowing them to work from home, or work 4 days a week, 10 hours a day

- $\quad$ Part-time job opportunities

- Job-sharing options - working in a team

- $\quad$ Flexible benefits - health, dental, eye - fringe benefits

- Voluntary demotions - allow them the chance to do an easier job in the company

- $\quad$ Active recruitment of older workers as company policy

- $\quad$ Accommodations for employees with physical limitations

- $\quad$ Longer vacation time

Many great people come from the baby boom era. Some of which are George W. Bush, Bill Gates, Dolly Parton, Donald Trump, Andrew Lloyd Weber, Tony Blair and Madonna along with many, many more models, actors, actresses, singers and songwriters, politicians, athletes and entertainers (www.seniorjournal.com).

As the Traditionalists and Baby Boomers age, the entire workforce ages. According to the Bureau of Labor Statistics (BLS),

During the 2002-2012 periods, the fastest-growing age groups are expected to be workers 55 and older. Young workers will enter the labor force, but at a much slower rate. The 35-44-year-old age group is actually expected to shrink, as baby boomers move into the older age groups and fewer workers enter this group. This combination of trends will cause the overall workforce to age (Noe, 2007, pg 32).

2002 Workforce by Age Group

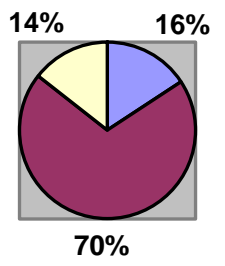

\section{Workforce by Age Group}

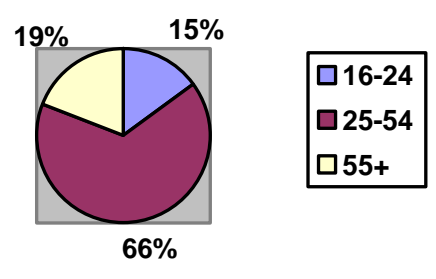

Because of the number of Baby Boomers that are aging, companies, especially the Human Resources departments need to shift their gears a little bit. They now have to worry about retirement funds and more healthcare expenses.

\section{GENERATION X}

The generation that is currently in the center of the workforce is Generation X, entering after the baby boomers, but before the Gen Yers. These are the children of the baby boomers. "This group accounts for about 41 million people" (Accounting Office Report, 2006, pg. 6), which happens to be the smallest portion of the population. Being a very educated group, these people are becoming the executives, managers and leaders now. Five key areas exist that should be focused on when working with this generation; company culture, management style, work environment, career development and work-life balance" (Gravett, 2006, Pg. 88).

One important quality to note about this generation is that they are very independent because the majority of them come from "divorced parents, dual-income families, and rearing in a latchkey program" (Gravett, 2006, Pg. 40). Some other characteristics consistent with many Gen Xers, according to the Accounting Office Management Administration Report they: 
- $\quad$ Grew up in a disturbing political environment, so they are suspicious of politics and may be cynical about the world around them.

- $\quad$ Are very sensitive to hype and insincerity.

- $\quad$ Are independent and self-reliant.

- $\quad$ Value teamwork and connection to a network of friends.

- Value flexibility, balancing the demands of their jobs and their personal lives is very important.

- $\quad$ Aren't intimidated by authority. Gen Xers are very outspoken. You'd better listen - they have a lot to say.

- $\quad$ Are results - and goal-oriented.

- $\quad$ Take a situational view rather than seeing things in black and white.

Since many people in this group grew up in broken homes with single parents having to work long hours to make ends meet, family is very important to them, along with finding a job that accommodates their family needs. They want to be able to work from home, so they can spend more time with their children. Since they are very result and goal-oriented, they will get their work done, from home or an office. They feel it should not make a difference where the work is done, as long as it is done on time and correctly.

In "Bridging the Generation Gap" by Linda Gravett and Robin Throckmorton, they mention some other ideas that companies should consider when trying to obtain, and retain employees from Generation X:

- $\quad$ Home-like work environment that is fun - toys and games as a stress reliever

- $\quad$ Flexibility - with schedules and days off

- A team oriented atmosphere

- $\quad$ High tech environment - the newest computers and software

- $\quad$ On and off-site training - on the job, and away at conferences

- $\quad$ Formal mentoring programs - Boomers and managers teaching the Xers what they know, and what they have done

- $\quad$ Management Styles

$\circ \quad$ Approachable

- Listens to ideas and suggestions

- Supportive of work/personal life balance

$\circ \quad$ High level of integrity

$\circ \quad$ Does not micro-manage

$\circ \quad$ Encourages and supports growth and development

$\circ \quad$ Recognizes good work through rewards

Many people refer to Generation X as the MTV generation, thinking they are lazy and have short attention spans. They are not lazy, but do have short attention spans. They need work that is challenging to them in order to keep them from becoming bored with their work. "They want to get in, do the work, and move on to the next thing" (Nagle, 2007).

Since a balance between work and personal life is so important, there are some suggestions listed for companies to consider in order to help accommodate this for their employees:

- $\quad$ Concierge services

- $\quad$ Paid and unpaid time off

- $\quad$ Flexible working hours - Four days a week, 10 hours a day

- $\quad$ Care packages for families when overtime is required

- $\quad$ On-site childcare / sick childcare

- $\quad$ Telecommuting - working from home when needed

One of the most important things to remember is that Generation $\mathrm{X}$ has more of a want and need to be with their families than the Baby Boomers did. As long as the companies and managers understand and support this, they 
will have a better chance at retaining them. "'Tailor' is the word used to summarize how to retain Gen Xers" (Gravett, 2006, Pg. 95).

Many famous politicians, musicians, singers, songwriters, models, actors, actresses and athletes that are members of the small, but important Generation X. A few examples are, Barack Obama, Sandra Bullock, Janet Jackson, Halle Barry, Andre Agassi, Ben Stiller and Julia Roberts (www.wikipedia.com).

\section{GENERATION Y}

The newest generation starting to enter the workforce, and strong, is Generation Y, or Gen Yers. They make up between 60 and 70 million people (Accounting Office Report, 2006, Pg. 6). The Yers are the children of the Xers and Boomers. Many of the older part of this generation are graduating from college now. Generation $\mathrm{Y}$ is far different from the generations that have come before. "They are sophisticated, aware of the world at large, multicultural, and nontraditional” (Accounting Office Report, 2006, Pg. 6).

For being such a young generation, there is much information available about the wants, needs and characteristics of this new generation. To start, they are very self-confident and are not easily intimidated, and do not tolerate it either. Growing up they were taught not to tolerate being bullied at the playground and school, they were to report it (Geisler, 2005). This is what they did, and this is what they are doing in the workforce.

Something else they were taught growing up was success. Many Gen Yers came from families where both parents had careers. These are parents that want something better for their children, for them to go to college and have a great career. This has left Gen Yers striving for success. Because their parents worked so much for them, and many came from divorced homes, this has made them value a work-life balance even more than the generations before them.

Because of their childhood, and the world around them while growing up, they have a different perspective on the world and life than any generation that has come before them. Many events have taken place for them to think differently than the older generations. One great example is $9 / 11$ and the events that have followed. Since that day, on any major news network there are pictures and videos of wars and battles taking place all over the world. According to Linda Gravett in "Bridging the Generational Gap", some of the different perspectives are:

- They are extremely conscious of the environment. They worry about our future, not just locally, but globally, and actively engage in and encourage acts of recycling and reducing wastes or pollutants.

- $\quad$ They are a diverse generation with an open mind and acceptance for differences in race, gender, ethnicity, sexual orientation, and so on.

- $\quad$ They are also an extremely expressive generation as evidenced by some of their dress, body jewelry, and brightly colored hair.

- $\quad$ They are very socially conscious and committed to any cause they value. Volunteering for their cause is important to them.

- Morally, interviews showed them to be much more against premarital and unprotected sex, alcohol, and drugs than Baby Boomers and Gen Xers.

For being such a new generation to the workforce, it is already known how to attract Gen Yers and keep them happy in the workplace. One way to do this by letting them know that you value their work. "Gen Ys realize they are young and less experienced than the other generations and have a lot to learn. They are eager to learn, but at the same time they want to be adding value to the organization" (Gravett, 2006, P. 98). Even though they are aware they have less experience, they are going to be impatient with promotions. They are not ones to want to get a promotion by seniority, if they prove they have the skills and abilities, along with education, they expect it to be recognized, and rewarded. If not, they will gladly go somewhere where they will be given the job.

A second way to retain a Gen Yer is by helping them to develop their careers. They want to learn and expand their skills as much as they can, while they are still early in the careers. Each person has his or her own 
ways of wanting to learn. A few examples from Bridging the Generation Gap by Linda Gravett and Robin Throckmorton are:

\begin{tabular}{ll} 
- & Coaching \\
- & Mentoring \\
- & Job Shadowing \\
- & Supporting role in a project \\
- & Tob rotation \\
\hline
\end{tabular}

Training can come in many forms such as on the job, online or in a classroom. However it is done, it needs to be technological and interactive.

The next step is to give them responsibility. Generation $\mathrm{Y}$ wants to improve themselves and add to their knowledge and skills and they thrive on responsibility. A few ways to give them responsibility are:

- $\quad$ "Allowing them to do a project their way as long as the end result meets the project needs.

- $\quad$ Providing them with multiple challenging assignments to manage at the same time with little guidance.

- $\quad$ Giving them an opportunity to be an active participant/partner on a team.

- $\quad$ Setting clear expectations for them and explaining 'why' they need to do something (then backing off and letting them do the work and seek the direction when needed).

- $\quad$ Allowing them to have the opportunity to actively get to know the business and what it takes for a business to succeed" (Gravett, 2006, P. 102).

Another way to help retain Gen Yers is to utilize technology. Generation Y grew up with computers and the latest technology. Having the newest and fastest computers and software will help keep them interested.

Providing recognition is the last important thing to do when trying to retain a Gen Yer. The computer, Xbox and Playstation games that this generation group up playing has helped establish their work styles. "Gen Ys are used to:

- $\quad$ Having very clear expectations of what they need to do.

- $\quad$ Receiving continuous assessments on where they stand.

- $\quad$ Obtaining constant feedback" (Gravett, 2006, P. 102).

Most companies offer a yearly performance review, which is fine for some people, but most Gen Yers require more than that. Some other examples of "recognition could include:

- $\quad$ Publicly recognizing the employee for his or her efforts.

- $\quad$ Writing a note to the employee.

- $\quad$ Personally thanking the employee for his or her efforts.

- Providing (even small) rewards (such as company-logo shirts, lunch with the CEO, Starbucks dollars, afternoon off or tickets to an event)" (Gravett, 2006, P. 103).

Lastly, since this generation seeks security and safety, reassuring them that they have job stability is a great way to keep them. If they feel there is even a chance that their job is on the line due to circumstances beyond their control, such as layoffs, they will start looking elsewhere. They want to have a new job before they lose the current one. "Gen Y workers are the most high-maintenance workforce in the history of the world. The good news is they're also going to be the most high-performing" (Martin, 2007, Pg. 39). 
Vice president of strategy and marketing at Yoh Services in Philadelphia told eWeek.com about "four steps to help companies effectively manage Generation Y workers' technological talents and maximize their value as employees" (www.eweek.com).

1. "Understand who this generation looks up to and how that relates to the misguided perception that they don't want to work" (www.eweek.com). Many people feel that this generation is lazy, and are full of slackers. This is not true, they do want to work, and they just want to work differently than generations before them. They are used to seeing people in the media getting rich fast, and this is what they want.

2. "They will switch jobs over the course of their careers more than any generation before them, holding as many as 20 jobs before they retire. The portability of retirement benefits and a lessened need to vest has contributed to this" (www.eweek.com). Managers need to understand that many Gen Yers think of each job as an experience to help them find their career down the road, and as a way to strengthen their skills. Employers need to remember that there is a possibility that these people who are leaving, will be back in a few years with more skills and experience.

3. "The way that Generation Y workers relate to their jobs is a demand for flexibility unseen in previous generations" (www.eweek.com). They feel that as long as their work is being done, then it should not matter where they are working from, or how long each day they are working for.

4. "They expect an open workplace where they can have their views heard without fear of retribution" (www.eweek.com). They feel that they should not fear the CEO of the company, but should be able to talk to them as an equal, and share their opinions without being looked down on.

While this generation comes with a great deal of benefits, and some downsides, some are also bringing their parents into the mix. In HR Magazine, Kathryn Tyler wrote an article titled "The Tethered Generation". In this article she discusses the fact that this generation has parents she likes to call "Helicopter Parents" because they hover over their children, even as they are becoming adults. This does cause some problems for the children as they grow and start to search for jobs and careers.

The main downside this has is that the children are not able to make even small mistakes because their parents will not let them. People need to make mistakes in order to learn from them. Jordan Grafman, who is the chief of the Cognitive Neuroscience Section at the National Institute of Neurological Disorders and Stroke, states that, "some hovering is good since some mistakes can be catastrophic" (Tyler, 2007, Pg. 42). Robert Epstein, a visiting scholar at the University of California in San Diego, and West Coast editor of Psychology Today feels that "parents' most important task is to help young people to become independent and autonomous. When we infantilize our young, we stifle their development" (Tyler, 2007, Pg. 42). People need to learn how to think for themselves and make their own decisions, and some parents of Generation Y are hindering this important ability.

Epstein gave some examples of hovering parents. One instance he remembers is when a student was caught cheating on a paper, and the student's mother called demanding that Epstein let him rewrite the paper. Ann Reynolds, director of university career services at Texas Christian University in Fort Worth has heard of similar experiences. There were instances where employers told her that parents would call to find out why their child was not offered more money, or turned down for a job. An increasingly common thing for parents to do is to go to work with their children and hang around for a few hours.

Along with the "Helicopter Parents" Tylers lists a few other traits Generation Y lacks:

- $\quad$ Discretion - With Myspace and Facebook available on the internet, Generation Y is generally not very secretive with their personal lives. This creates a problem when working with other people who are, and feel that the personal lives should be left at home. Yers are more open about themselves than other generations before.

- Independence - This stems back to the "Helicopter Parents" not letting them have their independence and experience life for themselves. The parents are hindering their abilities to make decisions in the workplace, which potentially hinders their ability to advance. 
- $\quad$ Realistic Expectations - This generation thinks they can go into a new job and change everything in one day. They grew up hearing how wonderful they are, and that they can achieve anything they put their minds to and then go to work and they are crushed. Another example would be salary and positions.

- $\quad$ Patience - Generation Y expects instant gratification, no matter what it is. After graduating from college they expect a top salary and to be in a top position. When they are waiting for work to be finished by somebody else, they want it yesterday. This is good because it makes them efficient in their work, but it makes it difficult to work with others.

- Work Ethic - While many people in this generation do work hard, it seems that they are doing it only for them, and lack loyalty to the company. They are willing to work, but on their terms, not the company's terms.

- $\quad$ Soft Skills and the Basics - Many members of this generation lack proper spelling and grammar skills, because of the spelling and grammar check tools available in documents and e-mail. Due to e-mailing, and text and instant messaging, many young people lack the face-to-face interpersonal skills.

While Generation Y possesses many excellent skills, traits and characteristics, there are some that need to be worked on, or around. It is important for employers and employees to realize that this generation is not like any of the others, and is quite stubborn about what they expect and want. It is also important for Generation Y to realize that the working world does not revolve around them and there are others out there with the important life and work experiences that they lack.

\section{WORKING TOGETHER}

Each generation has their own characteristics and traits, their own wants and needs when it comes to their professional and personal lives. Putting these differences together in such, a close space, like in an office, is obviously going to cause some problems. Learning how to get these generations to get along is very important for management in every company or organization to learn.

A very common problem in the workplace is Boomers having Gen Xer's or Gen Yer's as their superiors. Boomers have "paid their dues" and worked their way up the totem pole. Since they started working they have been used to doing things a certain way. Now they have to report to somebody that is, at the least, half their age, and more than likely has a different work ethic and "new" way of doing business. Some Boomers may feel cheated because they have so much experience and have worked their way up from the bottom, and in walks somebody fresh out of college, with no experience to direct, and lead them.

Another issue with Boomers having to work for somebody younger is how they work. Boomers feel there should be more time spent in the office, longer hours, along with a more professional atmosphere, while the younger generations want, and sometimes need, a balance between personal and professional lives. In addition, the younger generation likes a more home-like atmosphere at work, more relaxed and comfortable. You can even find offices with games in them, and younger people wearing flip flops and capris instead of the traditional suits.

The way the Baby Boomers and the younger generations need to be managed is quite different as well. Boomers require and prefer a more micro-managed approach, hands-on with the management watching and being hands on with projects and work every step of the way. On the other hand, Gen Xers and Gen Yers would rather be told what the finishing product should be, and be left alone to do their work. They do not care as much how it is done, as long as it is done correctly. When help is needed, they are not afraid to ask.

The most common problem in just about every workplace is conflict between younger and older generations, mainly Boomers and Generation Y. "Older employees are dismissive of younger workers' abilities, and younger employees are dismissive of the abilities of their older coworkers" (www.usatoday.com). One reason for these dismissive feelings is due to older employees feeling that the younger generations have a poor work ethic because they worry about their personal lives too much, and would rather work from home. Younger employees, in return, feel that the older employees are not "quick" enough to learn and adapt to ever changing technology. 
In order for the "generations at work...to become the generations united" there are four steps that Stephanie Wood, author of Spanning the Generation Gap in the Workplace suggests:

1. Everybody makes mistakes. Generations of all ages should take the lessons they have learned from mistakes in the past and pass those experiences on to fellow coworkers.

2. Older generations should take their extensive experience and expertise to teach and be mentors to the younger generations. The information the younger generations will learn will help them be ready for leadership opportunities that may arise.

3. Younger generations have to learn to be followers and be taught by the older generations. It is important to show that they are "trainable, flexible, self-motivated, and able to express their needs without rancor. The best leaders were at one time great followers."

4. "All generations must acknowledge and respect each other's differences as opportunities for self growth." By doing this they will be able to learn from others mistakes and challenges and be prepared for the future and be able to make better decisions than others did.

"There are two keys to creating a successful intergenerational workforce: aggressive communication and difference deployment" (Zemke, 2000, Pg. 153). With aggressive communication, conflicts that could potentially arise between the different generations are anticipated. Most generational differences are based on assumptions of the other generations. Bringing out these conflicts before they arise is "a giant step toward resolving them" (Pg. 153). "In the best and brightest intergenerational companies, overcommunication is the rule" (Pg. 154). Organizations like this organize group discussions, group projects, staff meetings and chats about different perspectives and views on vital issues, all including different generations.

"Difference deployment is, simply, the tactical use of employees with different backgrounds, experiences, skills, and viewpoints to strengthen project teams, customer contact functions, and, at times, whole departments and units" (Zemke, 2000, Pg. 154). Smarter companies are learning that each employee has different traits, strengths and weaknesses, and they are learning how to utilize these for the benefit of the company and the employee. Many companies that have not caught on yet have a stereotype of what the "perfect" employee is, and tries to hire sticking with those characteristics and traits. These people work fine right now, but things change everyday. Will these same employees benefit the company in the future?

In the book Generations at Work: Managing the Clash of Veterans, Boomers, Xers, and Nexters, in Your Workplace, the authors mention "five specific similarities or common approaches to making their environments generationally comfortable and focusing their people's energies on the business of the business" (Zemke, 2000, Pg. 156). The term they came up with for this is called the ACORN imperative.

1. Accommodate employee differences. Each employee, not just each Generation has his or her own wants, needs, icons, language and ethics. It is important for a company to learn these, just as they do with their customers. Accommodating to each employee will help to keep them happy, motivated, and with a company longer. It will also make the company more appealing to future employees.

2. Create workplace choices. If the younger generations want to feel more casual and comfortable, let them wear dress casual clothes instead of suits, but if the Boomers still want to wear their traditional suits, and then let them. As long as the work is being done on time and correctly, then having a more relaxed environment will be more attractive to many people, employees and customers.

3. Operate from a sophisticated management style. This means, in a sense, being less of a micro-manager, but more broad and to the point. Give the employees "the big picture, specific goals and measures, then turn them loose, giving them feedback, reward and recognition as appropriate. There are seven attributes that characterize their flexibility:

- $\quad$ Their supervisory style is not fixed. How closely they monitor and manage, for instance, are a product of each individual's record of accomplishment and personal preferences. Control and autonomy are a continuum, not solitary options. 
- $\quad$ Their leadership style is situationally varied. Some decisions are consensually made; others are made by the manager, but with input and consultation.

- $\quad$ They depend less on positional than on personal power.

- $\quad$ They know when and how to make personal policy exceptions, without causing a team riot.

- They are thoughtful when matching individuals to a team or a team or individual to an assignment.

- They balance concern for tasks and concerns for people. They are neither slave drivers nor country club managers.

- They understand the elements of trust and work to gain it from their employees. They are perceived as fair, inclusive, good communicators, and competent in their own right.

4. Respect competence and initiative. Each employee should be treated as if they have something great to offer the company, from the newest to the most seasoned employee. It is also important to match each employee to their work by utilizing their strengths.

5. Nourish retention. It is important to realize that there is a labor shortage in the world today, and that there is as much a need to keep their current employees, as there is to attract new ones. Offering different types of training from one-on-one coaching to classrooms to technology based computer training is a good way to do this. In addition, it is important to broaden assignments, give more responsibility and promote from within, instead of hiring out.

Another suggestion for companies planning to hire more Generation Yers, while keeping their Baby Boomers would be to train all the generations in various ways. Generation $\mathrm{Y}$ is taught the basics, such as how to dress and properly address customers and clients. Another area of training is to make sure that Boomers are aware of the technology and slang that these younger people use. It is important for all the generations to understand each other. It is an important move in helping everybody to get along. A few larger corporations have started doing this by having orientation for all ages. Some of these are Arrow Electronics, Aflac Insurance and the Orange County Employee Benefit Council (Belkin, 2007, Pg. D1).

Jennifer Deal, author of an article titled Generational Differences suggests employers and employees need to look past the stereotypes that the generations have been given and see the 10 truths about conflicts at work due to the generation gaps:

1. All generations have similar values. Each generation has different values, so does each person. However, there are common values that each generation does have in common such as "integrity, achievement, love competence, happiness, self-respect, wisdom, balance and responsibility".

2. Everyone wants respect. Stories are often told of younger generations not respecting their elders, or older people not respecting the young ones. Either way, all generations want respect, but respect has a different meaning to everybody. "Older people primarily talk about respect in terms of 'give my opinions the weight I believe they deserve' and 'do what I tell you to do'. Younger respondents characterize respect more as 'listen to me' and 'pay attention to what I say'."

3. Leaders must be trustworthy. People of all ages and generations want to work for and with people they know they can trust. Often, employees do not have very much trust for the organization and upper management itself, so they need to feel the people they work directly with are trustworthy.

4. People want leaders who are credible and trustworthy. This goes along with the previous one. Most people do not care about the age of their leader, they just want somebody to be "credible and trustworthy, to listen well, to be farsighted and encouraging."

5. Internal politics is a problem at any age. People that are not involved in office politics are the ones that do not like it. They just want to be able to be recognized for the work they have accomplished and be able to get what they need in order to do their jobs. However, some people do realize and feel that in order to climb the corporate ladder they need to be involved in the politics.

6. No one really likes change. Gen Yers have the stereotype that they like change, but nobody really likes it. "Resistance to change has nothing to do with age; it is all about how much you have to gain or lose as a result of the change." Change makes most people uncomfortable, regardless of age. 
7. Loyalty depends on the context, not the generation. People who put in more hours a day are not necessarily more loyal. The amount of hours put in a day depends on the job that is being done. Older generations are more likely to stay with a company longer than younger generations, not because of loyalty, but maybe because they are close to retirement.

8. It's as easy to retain a young person as it is to retain an older one-if you do the right things. For the most part, all generations want the same thing from a company in order to stay with them: "opportunities to advance, learning and development, respect and recognition, better quality of life and better compensation." If a company can provide these, there will be no problem retaining employees of all ages.

9. Everyone wants to learn more than just about anything else. All employees want to learn everything they can about doing their job. They also want to learn about other people's jobs, and what they need to learn to get to the next level. "Five developmental areas are important: leadership, skills training in their field of expertise, problem-solving and decision-making, team-building, and communication skills."

10. Almost everyone wants a coach. Everybody, no matter how old or young they are likes to hear how they are doing. Feedback, whether it is good or bad, whatever form it may come in is welcomed by all. However, most people would rather hear it from their coach or mentor than a coworker.

While it is important for employers, managers and supervisors to know how to successfully manage and lead these different generations, it is equally as important for all employees to be able to work together. Management should work with their employees on the subject, alone and in a group. This could help the employees to get to know each other better and to see why each person works and believes the way they do. Managers can be trained to lead all generations in the workplace, and employees can be trained to work together. Part of the training for both managers and employees requires an understanding of each generation. "To ensure continued success and groom leaders of the future, associations should implement routine discussions that will foster collaboration across generations" (Slate, 2007, 11).

Dana Kyles offers some strategies for better generational understanding in the workplace in her article titled Managing Your Multigenerational Workforce. Her first suggestion is to create assignments that are both function and project-oriented. This allows each generation to find where they fit in, where they can improve or develop new skills as well as what they are already experts at. The next tip she gives is to watch your mouth. Communication is very important no matter the age or company. You must know how to communicate with the generation you are dealing with. Younger generations are technically savvy so they may prefer to use e-mail or even text messaging while older generations tend to prefer face-to-face conversations. Also, it is important to know what to say, especially in an interview if you are trying to obtain a particular younger or older person. A Gen Yer is going to be turned off if the interviewer starts talking about long work hours and working on the weekend, while this may not bother a Boomer at all.

The third suggestion is to acknowledge employees strengths and weaknesses, and utilize them. If a specific task requires somebody with more experience, then assign it to a Boomer that is qualified, if it is a job that requires somebody technically savvy, then it will be more than likely that a Gen Yer will be the best benefit. If there is an assignment that requires a group effort, try to find employees from different generations, with professional commonalities to work on it together. Another important thing to remember is to listen to people. Some employees have trouble taking orders or advice from coworkers. No matter what age, everybody can bring something beneficial to the company. It is important for employers and employees to listen to ideas and advice from others.

Kyles' next piece of advice is to look beyond appearances. Each age group has different ideas of what style of clothing is professional and dress casual. Before shooting somebody down because of how they look, take the time to get to know them first. The last strategy is to have an open mind at all times. Not everybody fits into the specific characteristics of their generation. An older Gen Xer may have more characteristics of a Boomer, and an older Gen Yer may have more characteristics of a Gen Xer. "The main thing to keep in mind is that each generation has something valuable to add to the workplace" (Kyles, 2005, Managing Your Multigenerational Workforce).

Another idea for training would be to have a management consultant visit the company and lecture on some of the general behaviors and characteristics of these generations. This could also clear up some misunderstandings. 
Maybe coming from an expert, the younger generations could understand that it is possible for the older generations to understand the new technology. Sometimes it takes an outsider to point out the obvious.

No matter how it is done, it is important that each employee, no matter how high or low they are on the corporate ladder, understand they are going to work with people of all ages for as long as they are working. Most people spend more time with coworkers than they do their own families so it is vital to the company, and to their own well-being, that everybody be able to get along. It is the miscommunication that causes the failure in some companies.

In conclusion, it is important for companies, along with management and employees to remember these seven steps, along with remembering that communication is one of the most important things in any relationship, whether it is personal or professional. By doing this, it is possible for each generation to successfully work together as a team, for two common goals, their benefit and for the benefit of the company.

No matter what age group an employee falls into, there is one thing they all have in common, and that is that they all want the opportunity for achievement and advancement at work. Everybody wants to do something meaningful, and they want to do it well. "Smart leaders make sure they provide these opportunities to their people. Then they go about the task of rewarding them according to their individual needs" (McDonald, 2007, pg. 18). Rewards are something the age groups do not have in common, but they all do want them for their hard work and recognition. These rewards still come in second place to opportunity.

"Each generation brings a unique perspective to work related tasks. If we don't talk about why we are different and our different perspectives, we don't come to the best decisions. The more people are willing to invest in honest communication about these issues, the better the outcome" (Dittman, Generational Differences at Work). Companies, managers and leaders neet to recognize the differences that each of these generations has and then focus on their ideas and actions, and put them to good use. 'By looking through our 'generational eyes,' we can find the common ground to honor and leverage diversity at work" (Wood, 2005, Spanning the Generation Gap in the Workplace).

"As the association landscape continues to evolve, the ability to empathize and engage with people from all age groups will be an essential component of a true $21^{\text {st }}$-century leader" (Slate, 2007).

\section{REFERENCES}

1. Armour, S. (2005). Generation Y: They've arrived at work with a new attitude. Retrieved June 8, 2007, from http://www.usatoday.com/money/workplace/2005-11-06-gen-y_x.htm

2. Baby Boomer Facts You May Not Know. (2005). Retrieved June 10, 2007, from http://www.seniorjournal.com/NEWS/Boomers/5-12-12-BoomerFacts.htm

3. $\quad$ Belkin, L. (2007, August 3). Generation frustrated. Naples Daily News, p. D1, D7.

4. Belling, Elaine. Modern Workplace Must Learn to Appreciate Boomers. Retrieved October 20, 2007, from www.news-press.com

5. Carter, C., \& Carter, K. (2003). When Generations Collide. Who They Are. Why They Clash. Retrieved June 10, 2007, from http://www.etsu.edu/edc/EDC\%20Training\%20Handouts/When\%20Generations\%20Collide\%20final.ppt

6. Deal, Jennifer J. (2007, June). Generational Differences. Leadership Excellence, 24(6), 11. Retrieved October, 29, 2007, from ABI/INFORM Global database.

7. Dealing with Your New Generation Mix. (2004). Accounting Office Management \& Administration Report, 5-6.

8. Dittman, Melissa. (June, 2005). Monitor on Psychology. 36(6). Retrieved October 29, 2007, from http://www.apa.org/monitor/jun05/generational.html

9. Geisler, J. (2005). Boomer Bosses, Meet Your New Employees. Retrieved September 23, 2007, from http://www.poynter.org/column.asp?id=34\&aid=87617

10. Generation X. (2007). Retrieved June 10, 2007, from http://en.wikipedia.org/wiki/Generation_X 
11. Gravett, L., \& Throckmorton, R. (2006). Bridging the generation gap. How to get radio babies, boomers, gen xers, and gen yers to work together and achieve more. Franklin Lakes, NJ: Career Press.

12. Greenblatt, Alan. (2007, October). Aging Baby Boomers. CQ Researcher, 17(37), 1-36. Retrieved October 31, 2007, from http://library.cqpress.com/cqresearcher

13. Kyles, Dana. (2005). Managing Your Generational Workforce. Strategic Finance, 87(6), 52-55. Retrieved October 29, 2007, from ABI/INFORM Global database.

14. McDonald, Tom. (2007, November). A Season of Change. Successful Meetings, 12(56), 18. Retrieved December 3, 2007, from ABI/INFORM Global database.

15. Nagle, T. (n.d.). Coaching Generation X. Retrieved June 17, 2007, from http://www.coachingandmentoring.com/Articles/X's.html

16. Noe, R., Hollenbeck, J., et al. (2007). Fundamentals of Human Resource Management (33). New York: McGraw Hill.

17. Rothberg, D. (2006). Generation Y for Dummies. Retrieved June 8, 2007, from http://www.eweek.com/article2/0\%2C1895\%2C2008351\%2C00.asp

18. Slate, B. (2007, November). A Millennial Path to Leadership. Associations Now, 3(12), 11. Retrieved December, 10, 2007, from Business Source Complete database.

19. Wood, Stephanie. (2005). Spanning the Generation Gap in the Workplace. American Water Works Association Journal, 97(5), 86-87, 89. Retrieved October 29, 2007, from ABI/INFORM Trade \& Industry database.

20. Zemke, R., Raines, C., \& Filipczak, B. (2000). Generations at work. Managing the clash of veterans, boomers, xers, and nexters in your workplace. New York: American Management Association. 
NOTES 